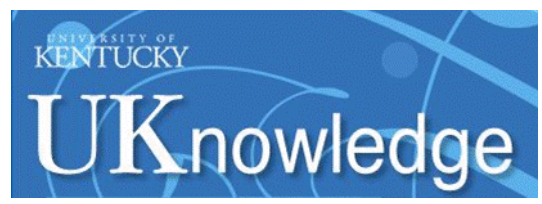

University of Kentucky

UKnowledge

\title{
Proposed Regulation A Amendments Implementing the Jobs Act: Please, SEC, Revise Your Proposed Amendments in Order to Promote Small Business Capital Formation
}

Rutheford B. Campbell Jr.

University of Kentucky College of Law, rcampbel@uky.edu

Follow this and additional works at: https://uknowledge.uky.edu/law_facpub_advocacy

Part of the Securities Law Commons

Right click to open a feedback form in a new tab to let us know how this document benefits you.

\section{Repository Citation}

Campbell, Rutheford B. Jr., "Proposed Regulation A Amendments Implementing the Jobs Act: Please, SEC, Revise Your Proposed Amendments in Order to Promote Small Business Capital Formation" (2014). Law Faculty Advocacy. 5.

https://uknowledge.uky.edu/law_facpub_advocacy/5

This Correspondence is brought to you for free and open access by the Law Faculty Publications at UKnowledge. It has been accepted for inclusion in Law Faculty Advocacy by an authorized administrator of UKnowledge. For more information, please contact UKnowledge@lsv.uky.edu. 
Proposed Regulation A Amendments Implementing the Jobs Act: Please, SEC, Revise Your Proposed Amendments in Order to Promote Small Business Capital Formation

\section{Notes/Citation Information}

Letter from Rutheford B Campbell, Jr., Professor, to Elizabeth M. Murphy, Secretary, U.S. Securities and Exchange Commission (March 5, 2014) (submitted electronically to rule-comments@sec.gov) 
PROPOSED REGULATION A AMENDMENTS IMPLEMENTING THE JOBS ACT: PLEASE, SEC, REVISE YOUR PROPOSED AMENDMENTS

IN ORDER TO PROMOTE SMALL BUSINESS CAPITAL FORMATION

\author{
Rutheford B Campbell, Jr. \\ Spears-Gilbert Professor of Law \\ University of Kentucky College of Law \\ Lexington, Kentucky \\ (859) 257-4050 \\ rcampbel@uky.edu
}




\begin{abstract}
The Jobs Act was enacted to promote efficient access to external capital by small businesses. Title IV of the Jobs Act raises the limit on the exemption from federal registration provided by Regulation A to $\$ 50$ million and requires the SEC to enact enabling regulations.

The Commission's first iteration of its proposed Regulation A amendments implementing Title IV of the Jobs Act fails to offer small businesses efficient access to external capital. Principally, this is because the proposed Regulation A amendments: (1) fail to preempt state registration authority over small offerings by small businesses relying on the proposed Regulation A amendments; and (2) fail to establish an appropriate balance in the disclosures required for small offerings by small businesses relying on the proposed Regulation A amendments.

If the Commission has the will to do so, these problems can be fixed by revising its proposed Regulation A amendments, thereby enabling Regulation A, after decades on non-use, to become an efficient vehicle for small business capital formation.
\end{abstract}


March 5, 2014

\title{
Submitted electronically to rule-comments@sec.gov
}

\author{
Elizabeth M. Murphy \\ Secretary \\ U.S. Securities and Exchange Commission \\ $100 \mathrm{~F}$ Street, NE \\ Washington, DC 20549

\section{Re: Rulemaking under Title IV of the Jobs Act ("Small Business Capital Formation")}

Dear Ms. Murphy:

I write to offer comments on the proposed amendments to Regulation A (Proposed Regulation A Amendments) implementing Title IV of the Jobs Act, as announced in the Commission's Release 33-9497 (December 18, 2013). ${ }^{1}$

\section{A. Overview of My Comments}

My comments are directed to the impact of the Commission's Proposed Regulation A Amendments on capital formation by small businesses. The matter with which my comments deal is the extent to which these proposed new rules provide an efficient access to external capital by small businesses.

By "small businesses" I mean businesses roughly similar to the size captured by the Small Business Association data on businesses with less than 20 employees. These truly small businesses are vital to our national economy, providing nearly $20 \%$ of all jobs. There are more than 5 million of these businesses in the United States and nearly all need external capital to survive and compete.

While in some instances these small businesses may need large amounts of capital, such small business often need less external capital than $\$ 50$ million (the limit of a Tier 2 offering under the Proposed Regulation A Amendments) or even $\$ 5$ million (the limit of a Tier 1 offering under the Proposed Regulation A Amendments).

Access to such smaller amounts of external capital by these businesses is especially difficult because of high relative offering or transaction costs. By "relative offering or transaction costs" I mean total offering costs (including, for example, legal and accounting costs) as a percentage of the total size of the offering. It is these relative (and not absolute) offering costs that often foreclose small businesses from

\footnotetext{
${ }^{1}$ Much of my comments and the text of my letter can be found in my forthcoming article in the Kentucky Law Journal, The New Regulation of Small Business Capital Formation: The Impact - If Any - of the Jobs Act.
} 
external capital.

A significant portion of my comments, therefore, is focused on the availability of the exemption from registration provided by the Commission's Proposed Regulation A Amendments for small businesses searching for small amounts of external capital, amounts of capital less than $\$ 5$ million.

Unfortunately, the Commission's Proposed Regulation A Amendments fail to offer small businesses an efficient access to the external capital they typically need. Stated in summary fashion, the failures of the proposed regulations are:

1. A failure to establish an appropriate balance in the disclosures required for small offerings by small businesses that are relying on the Proposed Regulation A Amendments; and

2. A failure to preempt state registration authority over small offerings by small businesses relying on the Proposed Regulation A Amendments.

Unless the Commission revises the Proposed Regulation A Amendments to deal effectively with these problems, the exemption under the new regulations will be effectively unused by small businesses searching for a small amount of external capital. In short, nothing will change for small businesses. Regulation A will continue to be useless to them.

These problems, however, can be fixed by the Commission, if it has the will to do so.

\section{B. Analysis of the Proposed Regulation A Amendments}

\section{Introduction}

Prior to the Jobs Act, Section 3(b) of the Securities Act of 1933 delegated broad authority to the Commission to enact regulatory exemptions from registration. The only limitations on the Commission's authority was that the regulatory exemptions could not exceed $\$ 5$ million and must be "in the public interest."

The Commission, acting under this delegated authority, enacted Regulation A. Regulation A allowed the issuer to make a public offering of its securities in an amount up to $\$ 5$ million. The exemption was predicated on the issuer's filing an offering statement with the Commission and providing each investor with an offering circular.

In its Regulation A rules, the Commission took pains to tailor the filing and disclosure requirements in a way that balanced investor protection with the capital formation needs of small businesses. The Commission also imposed no offeree or purchaser qualification requirements on Regulation A offerings (e.g., no sophistication or accredited investor requirements) or restrictions on the resale of Regulation $A$ securities.

At the time of the enactment of the Jobs Act, Regulation A was the only generally available exemption from the registration requirements of the 1933 Act that permitted an issuer to engage in a broad, interstate search for external capital. 
Notwithstanding the apparent attractiveness of Regulation A for offerings by small businesses, the Commission's carefully crafted regime turned out to be an utter failure. In recent years, Regulation A was essentially unused. ${ }^{2}$

The principal reason for the failure of Regulation $A$ is the registration requirements in state blue sky laws. A small issuer using Regulation A for a wide offering is required, in addition to meeting the requirements of Regulation $A$, to meet the registration requirements - either by registering the securities with the state or qualifying for an exemption - in each state where its securities are offered. The relative offering or transaction costs generated by state registration rules simply overwhelm any benefit small businesses may gain by using Regulation $A{ }^{3}$

Title IV of the Jobs Act adds new Section 3(b)(2) to the 1933 Act. $^{4}$ That section directs the Commission to enact new regulations providing an exemption from registration for offerings of up to $\$ 50$ million. Delegation of rule making authority to the Commission under this new Section 3(b)(2) is broad.

With regard to the matter of preemption, the Jobs Act amends the National Securities Markets Improvement Act (NSMIA) to provide two bases for preemption of state registration authority over securities sold in a Section 3(b)(2) offering. First, state authority is preempted if those securities are "offered or sold on a national securities exchange." The other basis for federal preemption of state authority over registration is if the securities in a Section 3(b)(2) offering are "offered or sold to . . . qualified purchaser[s], as defined by the Commission ...."

The legislative delegation of authority to the Commission in Title IV of the Jobs Act offers the Commission an opportunity to construct a new Section 3(b) regulatory exemption from registration that is efficient for small issuers and sound as a matter of financial policy. To achieve these benefits, however, the Commission, within the scope of its delegated authority, must enact regulations that balance investor protection and capital formation. Unfortunately, the Commission's proposed rules fail to achieve this balance.

The Commission's Proposed Regulation A Amendments fail to offer small businesses in search of a small amount of external capital an efficient disclosure regime or a sensible preemption option.

${ }^{2}$ See Rutheford B Campbell, Jr., Regulation A: Small Businesses' Search for “A Moderate Capital", 31 Del. J. CoRP. L. 77, 83 (2006) (hereinafter, "Campbell, A Moderate Capital") (data showing that during a 10 year period ending in 2004 there were on average only 7.8 Regulation A offerings per year), and Rutheford B Campbell, Jr., Regulation A and the Jobs Act: A Failure to Resuscitate, 7 OHIo St. Entrep. Bus. L. J. 317, 321 (2012) (during a 7 year period ending in 2011 there were on average only 23.1 Regulation A offerings per year).

${ }^{3}$ See Campbell, A Moderate Capital, supra note 2, at 106-112.

${ }^{4} 15$ U.S.C. $\$ 77(c)(b)(2)(2013)$. Title IV of the Jobs Act, entitled "Small Business Capital Formation", changes nothing with regard to former Section 3(b) of the 1933 Act, now renumbered as Section 3(b)(1) of the 1933 act. 


\section{Matters of Disclosure and Preemption in Proposed Regulation A Amendments}

The following offers an analysis of the problems in the Proposed Regulation A Amendments and suggests how the Commission might adjust those proposed rules to ensure that Title IV of the Jobs Act, which is entitled, Small Business Capital Formation, in fact offers small businesses an efficient access to external capital in their capital formation efforts.

I divide my comments into Tier 1 offerings (offerings of a size not exceeding $\$ 5$ million) and Tier 2 offerings (offerings of a size not exceeding $\$ 50$ million). There is no lower limit for Tier 2 offerings (i.e., offerings of $\$ 5$ million or less can be made under the Tier 2 regime).

The requirements for an exemption from registration in the Proposed Regulation A Amendments differ, depending whether the issuer is proceeding as a Tier 1 offering or a Tier 2 offering.

\section{a. Tier 1 Offerings for Small Businesses}

Without significant adjustments by the Commission, it seems unlikely that small issuers will rely on Tier 1 offerings under the Proposed Regulation A Amendments.

\section{(1) Disclosure Requirements}

While the Commission in its Proposed Regulation A Amendments attempted to tailor its disclosure requirements, the prescribed disclosures in a Tier 1 offering are still quite significant. In Tier 1 offerings, the proposed Form 1-A, which provides requirements for both the offering statement and the offering circular, requires 14 items of narrative disclosures, plus financial disclosures.

The primary difficulty with the disclosure obligations proposed for Tier 1 offerings is in smaller offerings, for examples, in offerings of approximately $\$ 2$ million or less. The problem in such smaller offerings is that relative offering costs bulk large, and high relative offering costs are likely to foreclose issuers from utilizing a particular exemption.

The Commission's achieving a balance in this matter directly impacts the tension between investor protection and capital formation, and it is always a difficult problem for the Commission. In the case of small Tier 1 offerings, the Commission needs to revisit the disclosure balance it struck in its Proposed Regulation A Amendments.

The answer may be a stepped disclosure obligation, with three (rather than two)

levels. Perhaps the steps would be: offerings of $\$ 2$ million or less; offerings of $\$ 5$ million or less; and offerings of $\$ 50$ million or less.

My own view is that in the latter two categories, offerings of $\$ 5$ million or less, and offerings of $\$ 50$ million or less, the Proposed Regulation A Amendments have it about right. The relative offering costs generated by the disclosure requirements in such larger offerings are not so high as to foreclose issuers from using the new rules. 
It is the lowest of the steps - offerings of $\$ 2$ million or less - where I would urge the Commission to reconsider its disclosure requirements, and in that regard I would offer following observations and comments.

In such small offerings (and, indeed, in all offerings of $\$ 5$ million or less), the Commission is right not to require post offering periodic reporting as a result of Tier 1 offerings. Periodic reports will be daunting to small businesses and serve no significant benefit.

Two of the most complex (i.e., expensive) disclosures one finds in proxy statements and Form 10-Ks are compensation disclosures and management's discussion and analysis. Limiting those disclosures in offerings of \$2 million or less would be helpful. One thing to keep in mind is disclosures under the Proposed Regulation A Amendments will most likely be orchestrated by counsel who is experienced in securities matters and familiar and comfortable with Regulation S-K. One would expect such counsel to err on the side of more expansive disclosures, informed by her or his experience in 1933 Act and 1934 Act disclosures. ${ }^{5}$ The Commission should offer clear guidance on these particular disclosures, indicating that less than Regulation S-K disclosures is adequate.

In financial disclosures, the Commission is right to not require audits or compliance with Regulation SX for small offerings. But the Commission should return to the prior Regulation A financial requirements of a one year balance sheet rather than 2 years. This, once again, requires the Commission to exercise its accumulated experience and judgment, but for smaller offerings strong arguments can be made that the prior Regulation A regime of a one year balance sheet offers a better balance.

To summarize my comments on disclosures, the most important matter is to add a third step or level to disclosure obligations and to consider reducing - at least somewhat - the disclosures for offerings of $\$ 2$ million or less. With regard to the higher two steps - offerings of $\$ 5$ million or less and offerings of $\$ 50$ million or less, - the disclosure requirements in the Proposed Regulation A Amendments are, in my view, appropriate.

\section{(2) Preemption}

While disclosure predicates to the availability of Tier 1 offerings to small businesses need attention, the major problem in Tier 1 offerings - and one that seems nearly certain to foreclose small businesses from use of the Tier 1 regime - is the failure of the proposed rules to preempt state authority over registration of Tier 1 offerings.

With regard to preemption of state authority over registration in Tier 1 offerings,

${ }^{5}$ Perhaps Item 11 of the proposed Form 1-A, 17 C.F.R. $§ 239.90$, Item 11 (2014), "Compensation of Directors and Officers", is the best example of this. Although the Item and its instructions amount to less than one page of Form 1-A, it seems certain the experienced counsel would rely heavily on Regulation $\mathrm{S}-\mathrm{K}$ disclosures regarding compensation of officer and directors, which regulations and instructions literally go on for tens of pages. See 17 C.F.R. $\S$ 229.402 (2013). 
the Proposed Regulation A Amendments preempt state registration authority over the offers of such securities but not over the sales of those securities. This proposed preemption rule is both curious and unfortunate, and it is ineffective to protect small business issuers from the pernicious impact that state authority over registration has on small business capital formation. Indeed, the preemption rule in its present form most likely amounts to the death knell for Tier I offerings.

To understand the problems of a small business issuer attempting to meet the state registration requirements in a Tier 1 offering, imagine a situation in which a small business issuer proposes to offer its securities broadly in all 50 states. Assume that the issuer gets indications of interest from potential investors in ten states and thus proposes to sell its securities under the proposed Regulation A rules in a Tier 1 offering in all ten of those states. The issuer still has to meet the registration requirements respecting sales in each of those states, and there is, as a result of the proposed preemption rule, a significant new complication regarding the issuer's meeting the states' sales requirements.

Assume - as may be the case - that the small business issuer proposes to rely on the states' limited offering exemption as a way of meeting the states' registration requirements. The conditions for some of those state exemptions will almost certainly involve strict limitations on offers by the issuer. Consider as an example the requirements for a small offering exemption under the Uniform Securities Act. That exemption is predicated on the issuer's meeting three conditions: (1) no more than ten offers; (2) a reasonable belief that the buyers are purchasing for investment; and (3) no commission paid to intermediaries in connection with the offering.

What is unclear, however, is the impact of the federal preemption of state authority over Tier 1 offers. What does that preemption do to the sale requirements for a state's small offering exemption? Does the preemption merely mean that the original broad solicitation by the small business issuer enjoys the benefit of preemption with regard to the broad offer, leaving the exemption for the sale dependent on the issuer's meeting, for example, all the three conditions described above, including the ten offer limit? Or, does the preemption change the conditions for a sale pursuant to the state small offering exemption, with the result that a small business issuer meets the requirements for an exempt sale under state's small offering exemption if the issuer meets only the other two conditions described above - (2) buyers purchasing for investment and (3) no commissions paid.

Neither interpretation seems appropriate. The first interpretation - that the state's exemption with regard to the sale still requires limited offers - essentially neutralizes preemption over offers. The second - that the state's exemption can now be met merely by purchasing for investment and no commissions - essentially changes the state small offering exemption to permit an unlimited number of sales of unregistered securities, an outcome that arguably is inconsistent with the policy bases for the legislative decision to exempt such sales.

Alternatively, a state court might simply declare the state exemption entirely nullified - and thus unavailable - as a result of the federal preemption over the offer. By eliminating the principal condition for the exemption, the entire exemption, a court might find, simply fails.

As a result, if the Commission holds to its proposed preemption rule, it seems 
unlikely that small businesses will make Tier 1 Regulation A offerings. The expense of attempting to qualify the sale under multiple state exemptions, especially when complicated by uncertainty and risk caused by the terms of the proposed preemption rule, will likely make Tier 1 offerings practically unavailable for small businesses in search of a relatively small amount of external capital.

The Commission should revise proposed rule 17 C.F.R. $\S 230.256$ to define a "qualified purchaser" to include any offeree or purchaser of any security issued under Regulation A.

\section{b. Tier 2 Offerings by Small Businesses}

While small businesses may move their small offerings under the Proposed Regulation A Amendments to a Tier 2 offering, since there is no lower threshold for Tier 2 offerings, Tier 2 requirements will not work for small businesses seeking a small amount of external capital.

The problem with Tier 2 for small businesses is not preemption, however. The proposed Tier 2 rules offer an effective preemption of state registration authority, preempting state authority over all Tier 2 offers and sales. ${ }^{6}$

The problem for small businesses' moving their small offerings to Tier 2 is the disclosure requirements, which are significantly more burdensome than the Tier 1 disclosure requirements.

Tier 2 financial statements, unlike financial statements in a Tier 1 offering, must be audited and compliant with a significant part of Regulation S-X. While this is not an insignificant increase in disclosure obligations, the big disclosure change imposed on Tier 2 offerings is the post offering periodic reporting requirement. Issuers in Tier 2 offerings pick up obligations to file with the Commission annual reports, semiannual reports and current reports, which will amount to a significant obligation for any small business issuer. The annual report, for example, must contain nearly the same information as the original offering statement, except for information about the original offering itself. The financial disclosures in the annual report require annual, two year, audited statements that are GAAP compliant and compliant with Article 8 of Regulation $\mathrm{S}-\mathrm{X}$. These obligations continue until the issuer drops below 300 shareholders of record.

For Tier 2 offerings of between $\$ 5$ and $\$ 50$ million, those disclosure obligations do not seem overly burdensome. Meeting the disclosure obligations for offerings of

${ }^{6}$ Section 18(a)(1)(A) of the Securities Act of 1933, 15 U.S.C. 77r(a)(1)(A), preempts state authority over registration with regard to the offer or sale of a "covered security". Section 18(b)(3) of the Securities Act of 193315 U.S.C. 77r(b)(3) (2013), includes in the definition of a "covered security" a security offered or sold to "qualified purchasers, as defined by the Commission by rule."

Proposed Regulation A rule 256, 17 C.F.R. $\S 230.256$ (2013), states: "For the purposes of Section 18(b)(3) of the Securities Act [15 USC 77r(b)(3)(2014)], a 'qualified purchaser' of a security offered or sold pursuant to Regulation A means any offeree of such security and, in a Tier 2 offering, any purchaser of such security." 
such sizes should not generally drive relative transaction costs to inefficient levels. For small businesses selling a small amount of securities, however, such enhanced disclosure obligations are likely to drive relative offering costs to levels that eliminate Tier 2 Regulation A offerings as a viable alternative for capital formation.

As a result, Tier 2 offers no practical alternative for small offerings under the Proposed Regulation A Amendments.

\section{Conclusion}

An efficient access to external capital by businesses is essential to a market economy. Small businesses, which amount to a vital component of our market economy, face not only structural and economic disadvantages but also legal obstacles in their search for essential external capital.

The Jobs Act, at least apparently, was aimed at reducing inefficient legal rules governing small businesses' access to capital. While the act itself is something of a mess, it did offer the Commission an opportunity to construct regulatory regimes to ameliorate the problems of small businesses in regard to capital formation. The Commission, however, failed to take full advantage of this opportunity in its Proposed Regulation A Amendments.

Without significant attention and revisions, the exemption from registration in the Proposed Regulation A Amendments is likely to be essentially unavailable for small businesses. The problems in the proposed rules, however, are fixable, if the Commission has the will.

Sincerely,

Rutheford B Campbell, Jr. Spears-Gilbert Professor of Law

University of Kentucky

College of Law

Lexington, Kentucky 40506

(859) 257-4050

rcampbel@uky.edu 